\title{
PROGRAM INFORMACIJSKO \\ OPISMENJAVANJE TINEJDŽERA \\ GRADSKE KNJIŽNICE ZADAR
}

\author{
ZADAR PUBLIC LIBRARY \\ TEENAGER INFORMATION LITERACY PROGRAM
}

\author{
Vera Vitori \\ Gradska knjižnica Zadar \\ vvitori@gkzd.hr \\ Petra Stulić \\ Gradska knjižnica Zadar \\ petra.stulic@gkzd.hr \\ Matea Bakmaz \\ Gradska knjižnica Zadar \\ matea.bakmaz@gkzd.hr
}

UDK / UDC [021.2-053.6:004(495.5 Zadar)]:374 Izvorni znanstveni rad / Original scientific paper Primljeno / Received: 27.3.2018.

Prihvaćeno / Accepted: 29.6.2018.

\section{Sažetak}

Cilj. Rad ukazuje na važnost provođenja programa informacijskog opismenjavanja u narodnim knjižnicama. Cilj je rada prikazati program Informacijsko opismenjavanje tinejdžera Gradske knjižnice Zadar i rezultate istraživanja koje je provedeno radi vrednovanja programa. U istraživanju se analizira zadovoljstvo i mišljenje sudionika programa, učenika osnovnih i srednjih škola, s obzirom na njegovu jasnoću, razumljivost, korisnost i zanimljivost.

Vjesnik bibliotekara Hrvatske 61, 1(2018), 127-150

ISSN 0507-1925

(C) VBH 2018. 
Metodologija. U anketnom istraživanju programa Informacijsko opismenjavanje tinejdžera za prikupljanje podataka korišten je anketni upitnik kreiran za tu svrhu.

Rezultati. Rezultati istraživanja pokazali su da je u narodnoj knjižnici moguće osmisliti i provesti kvalitetne programe poput programa Informacijsko opismenjavanje tinejdžera u Gradskoj knjižnici Zadar. Rezultati pokazuju da učenici osnovnih i srednjih škola u velikom postotku pozitivno ocjenjuju zanimljivost teme, jasnu i razumljivu prezentaciju sadržaja i stjecanje novih znanja za koja smatraju da će im koristiti u daljnjem školovanju.

Originalnost. Rad nastoji ukazati na potrebu provođenja programa informacijskog opismenjavanja, kakav je za tinejdžersku populaciju u narodnoj knjižnici rijetkost. Opisujući faze nastanka, koncept i promidžbene aktivnosti programa Informacijsko opismenjavanje tinejdžera Gradske knjižnice Zadar, dan je model za oblikovanje srodnih programa. U hrvatskoj stručnoj literaturi nedovoljno je istraživanja na temu informacijske pismenosti u narodnim knjižnicama, a vrednovanja programa opismenjavanja tinejdžera gotovo da i nema. Rezultati vrednovanja programa s obzirom na učenike osnovnih i srednjih škola mogu poslužiti kao polazište u formiranju sadržaja sličnih programa te kao smjerokaz za unapređivanje postojećih.

Ključne riječi: Gradska knjižnica Zadar, informacijska pismenost, narodne knjižnice, program Informacijsko opismenjavanje tinejdžera, učenici osnovne škole, učenici srednje škole, vrednovanje

\section{Abstract}

Objective. The paper stresses the importance of information literacy programs in public libraries. The aim of the paper is to present the Zadar Public Library Teenager Information Literacy Program and the results of the research conducted in order to evaluate the Program. The research analyizes the contentment and opinion of Program participants - elementary and high school students, with respect to clarity, comprehensibility, usefulness and interestingness of the Program.

Methodology. In order to conduct the research of the Information Literacy Program a questionnaire was created for data collection.

Results. The research results have shown that within the context of a public library it is possible to create and undertake quality information literacy programs such as Teenager Information Literacy program in Zadar Public Library. The results of evaluation demonstrate that elementary and high school students in large percentage evaluate positively the interestingness of the topic, clear and understandable presentation of the content and acquisition of new knowledge that they consider useful in further education.

Originality. The paper seeks to point out the necessity of undertaking information literacy programs for teenagers which occur rarely in public libraries. Describing the 
phases of emergence, the concept and the promotional activities of Zadar Public Library Teenager Information Literacy program, a model for shaping of similar programs was given. In Croatian professional literature there is insufficient research on the topic of information literacy and evaluation of teenager information literacy programs is virtually nonexistent. Results of evaluation of the Program for elementary and high school students may serve as a starting point for shaping of the content of similar programs and as guidelines for the improvements of the existing programs.

Keywords: elementary school students, evaluation, high sschool students, information literacy, public libraries, Teenager Information Literacy program, Zadar Public Library

\section{Uvod}

Informacijska pismenost sintagma je koja se nametnula kao imperativ vremena u kojem živimo i jedna je od važnijih sastavnica čovjekove pismenosti uopće, te je stoga i prozvana pismenošću za 21. stoljeće. Od mladih se, s obzirom na to da pripadaju tzv. Google-generaciji i odrastaju u okruženju informacijsko-komunikacijske tehnologije, očekuje da budu informatički i informacijski pismeni. Usto, u ciljevima i zadacima hrvatskih strateških dokumenata u području odgoja i obrazovanja u osnovnoj i srednjoj školi, kao i u zakonskim aktima i dokumentima školskih i narodnih knjižnica, prisutan je sadržaj informacijske pismenosti. ${ }^{1}$

Budući da istraživanja na temu informacijske pismenosti među učenicima osnovnih i srednjih škola u Hrvatskoj ima malo ${ }^{2}$, o razini njihove informacijske pismenosti ne može se govoriti sa sigurnošću, pa se možemo prikloniti sljedećoj konstataciji:

„Diskurs u kojemu prevladava načelna percepcija digitalnog urođenika koji, a priori, vješto koristi tehnologije, ne donosi osobito pre-

\footnotetext{
1 Iako se u nekim od dokumenata izrijekom ne spominje informacijska pismenost, o nekim sadržajima informacijske pismenosti govori se implicitno. Vidi dokumente: Zakon o odgoju i obrazovanju u osnovnoj i srednjoj školi (pročišćeni tekst). // Narodne novine 126, 2705(2012). [citirano: 2018-06-04]. Dostupno na: https://narodne-novine.nn.hr/clanci/ sluzbeni/2012_11_126_2705.html; Nastavni plan i program za osnovnu školu. 2013. [citirano: 2018-06-04]. Dostupno na: https://mzo.hr/sites/default/files/migrated/nastavni_plan_i_program za_os_2013.pdf; Zakon o knjižnicama. // Narodne novine 10, 1616(1997). [citirano: $2018-06-04]$. Dostupno na: https://narodnenovine.nn.hr/clanci/sluzbeni/1997_10_105_1616.html; Standardi za narodne knjižnice u Republici Hrvatskoj. [citirano: 2018-06-04]. Dostupno na: https://narodne-novine.nn.hr/clanci/sluzbeni/1997_10_105_1616.html; Standard za školske knjižnice. // Narodne novine 34, 698(2000). [citirano: 2018-06-04]. Dostupno na: https://narodne-novine.nn.hr/ clanci/sluzbeni/2000_03_34_698.html.

$2 \mathrm{O}$ istraživanjima više u nastavku teksta.
} 
ciznu i objektivnu sliku o tome kako mladi doista koriste tehnologije u svrhu dolaženja do informacija na temelju kojih donose odluke. ${ }^{\text {"3 }}$

Narodna knjižnica, kao mjesno obavijesno središte, ima zadaću pružati podršku obrazovanju, što otvara mogućnost za organiziranje programa za stjecanje vještina informacijske pismenosti. Promišljajući o važnosti obrazovne uloge i međuinstitucionalne suradnje, Gradska knjižnica Zadar pokrenula je program Informacijsko opismenjavanje tinejdžera. Program se provodi od prosinca 2016. godine, a namijenjen je učenicima viših razreda osnovnih škola, učenicima srednjih škola, kao i ostalim zainteresiranim pojedincima $\mathrm{i} / \mathrm{ili}$ skupinama. $\mathrm{U}$ svrhu vrednovanja programa među učenicima osnovnih i srednjih škola provedeno je istraživanje metodom ankete, kako bi se doznalo njihovo mišljenje o programu te zadovoljstvo jasnoćom, razumljivošću, korisnošću i zanimljivošću prezentiranog sadržaja s ciljem njegova usavršavanja.

\section{Informacijska pismenost}

\subsection{Povezanost informacijske pismenosti i obrazovne uloge narodnih knjižnica}

Za informacijsko-komunikacijsku tehnologiju možemo reći da uvelike prožima sve vidove profesionalnog, građanskog i osobnog života. Informacijski i medijski teoretičari ističu društvenu važnost informacije u tolikoj mjeri „da se pojam informacija uzdigao na pijedestal naziva jedne cijele epohe u neologizmu informacijsko društvo“. ${ }^{4}$ Takvo društvo iznjedrilo je i nove oblike pismenosti, a kao izrazito potrebnu i informacijsku pismenost, čiji se koncept pojavio vezano uz transformacije u društvenom kontekstu i u užem je smislu nastao kao posljedica progresivnog rasta informacija, slijedom čega postaje neupitna činjenica da danas, prema Maletiću, nemamo problem s informacijama, već s „orijentacijom“.5

Prvi terminološki iskaz informacijska pismenost nastao je 1974., a općeprihvaćena definicija 1989. ${ }^{6}$ Mnoge druge definicije, koje su razvile stručne ili obrazovne organizacije, nastale su prije naglog razvoja društvenih medija i novih, prema Lasić, hibridnih, hipermedijskih, elektroničkih i mrežnih obrazovnih prostora. ${ }^{7}$ Najcitiranija definicija informacijske pismenosti potječe od Američkog knjižničarskog društva

\footnotetext{
3 Lazić-Lasić, J.; S. Špiranec; M. Banek Zorica. Izgubljeni u novim obrazovnim okruženjima - pronađeni u informacijskom opismenjivanju. // Medijska istraživanja 18, 1(2012), 125-142. Dostupno i na: https://hrcak.srce.hr/85384 [citirano: 2018-01-25].

${ }^{4}$ Usp. Maletić, F. Informacija je ponovo „in“. // In Medias res 3, 5(2014), str. 719. Dostupno i na: https://hrcak.srce.hr/127202 [citirano: 2018-02-15].

5 Usp. isto, str. 720.

${ }^{6}$ Usp. Špiranec, S.; M. Banek Zorica. Informacijska pismenost: teorijski okvir i polazišta. Zagreb: Zavod za informacijske studije, 2008. Str. 43.

7 Usp. Lasić-Lazić, J; S. Špiranec; M. Banek Zorica. Nav. dj., str. 127.
} 
(engl. American Library Association, ALA), prepoznata je kao dovoljno široka i primjenjivana je desetljećima. ${ }^{8}$ Iz te definicije proizlazi da informacijski pismena osoba prepoznaje potrebu za informacijom, pronalazi ju, vrednuje i učinkovito koristi, a na temelju poznavanja načina na koji je znanje organizirano naučila je kako učiti. ${ }^{9}$

Danas, trideset godina nakon navedene definicije, informacijska pismenost najuže je povezana s područjem obrazovanja jer je vezana uz nove pristupe učenju, teorije obrazovanja i potrebu za cjeloživotnim učenjem. ${ }^{10}$

Obrazovana uloga bit je poslanja svake knjižnice, a obrazovna uloga narodne knjižnice definira ju kao središte učenja za lokalnu zajednicu, jer sve očiglednije potrebe za učenjem prelaze formalne okvire obrazovanja. Učenje u formalnom i neformalnom okružju služi unapređivanju znanja, vještina i kompetencija u svrhu osobnog razvoja i razvoja zajednice. Potreba za učenjem u svim razdobljima života nametnula je princip cjeloživotnog učenja koji je postao sastavnim dijelom raznih strategija. Upravo taj princip povezao je informacijsku pismenost s aktivnostima narodne knjižnice. Imajući ga u vidu, narodna knjižnica može jasnije definirati srž obrazovnog djelovanja, obrazovne aktivnosti razvijati prema informacijskoj pismenosti i oblikovati konkretne programe informacijskog opismenjavanja. Radi se o evoluciji edukacije korisnika, jer su mnogi programi edukacije izmijenjeni u programe informacijske pismenosti na način da se zadovolje potrebe korisnika u sve složenijem informacijskom okružju. ${ }^{11}$

\subsection{Pregled domaće literature i inicijativa povezanih $s$ informacijskom pismenošću}

O informacijskoj pismenosti, s teorijskog i praktičnog gledišta, pisali su do sada mnogi domaći autori. Početak intenzivnijeg bavljenja tom problematikom predstavlja tematski broj časopisa Edupoint ${ }^{12}$ iz $2003 .{ }^{13}$ Posvećen je informacijskoj pismenosti, premda donosi i članke na temu informatičke pismenosti. Tema informacijske pismenosti obrađena je s teorijskog gledišta u članku Informacij-

\footnotetext{
${ }^{8}$ Usp. Lau, J. Smjernice za informacijsku pismenost u cjeloživotnom učenju: završna verzija. Recenzirano 30. srpnja 2006. Zagreb: Hrvatsko knjižničarsko društvo, 2011. Str. 21.

9 Usp. isto.

${ }^{10}$ Usp. Špiranec, S; M. Banek Zorica. Nav. dj., str. 21-22.

${ }_{11}$ Usp. Špiranec, S. Informacijska pismenost: ključ za cjeloživotno učenje. // Edupoint 3(2003). [citirano: 2018-06-03]. Dostupno na: http://edupoint.carnet.hr/casopis/17/clanci/1.html.

12 Vidi: Edupoint : časopis o primjeni informacijskih tehnologija u obrazovanju, broj 3 iz 2003. godine. [citirano: 2018-06-03]. Dostupno na: http://edupoint.carnet.hr/casopis/17.html.

${ }^{13}$ Usp. Jokić, A.; D. Koljenik; S. Faletar Tanacković; B. Badurina. Vještine informacijske i informacijske i informatičke pismenosti studenata informacijskih znanosti u Osijeku: pilot istraživanje. // Vjesnik bibliotekara Hrvatske 59, 3-4(2016), 67-68. Dostupno i na: https://www.hkdrustvo. $\mathrm{hr} / \mathrm{vjesnik-bibliotekara-hrvatske/index.php/vbh/article/view/501/47} \mathrm{[citirano:} \mathrm{2018-05-03].}$
} 
ska pismenost - ključ za cjeloživotno učenje $e^{14}$, u kojem ju S. Špiranec smješta i u kontekst knjižnica, navodeći da se kod nas, u tom trenutku, ne problematizira informacijsko opismenjavanje korisnika. U radu iz 2004. pod naslovom Obrazovna uloga knjižnica, priprema građana za Europu znanja ${ }^{15}$ Špiranec i Lasić-Lazić pristupaju temi informacijske pismenosti u kontekstu dokumenata Europske unije i obrazovne uloge knjižnica.

Značajan doprinos glede spoznaja o informacijskoj pismenosti, razvoju i njezinoj primjeni predstavlja knjiga Špiranec i Banek Zorice Informacijska pismenost: teorijski okvir i polazišta iz 2008. ${ }^{16}$, u kojoj se fenomen informacijske pismenosti promatra kroz prizmu evolucije koncepta, određenja pojma, relevantnih istraživanja i različitih okruženja primjene, pa tako i u narodnoj knjižnici. Specifičnost je narodne knjižnice u oblikovanju programa informacijske pismenosti velika protežnost sadržaja i široka korisnička populacija.

Svezak: časopis Društva knjižničara Bilogore, Podravine i Kalničkog prigorja ${ }^{17}$ iz 2010. posvećen je informacijskoj pismenosti. Novina je u tome što se o temi piše vezano uz narodne knjižnice i s navođenjem primjera programa informacijskog opismenjavanja. U članku Informacijska pismenost? Da, mi to možemo... „, Yes, we can "18 Špiranec i Banek Zorica navode, između ostalog, da je princip cjeloživotnog učenja privukao koncept informacijske pismenosti u narodne knjižnice. U članku Poučavanje djece i mladih informacijskoj pismenosti u knjižnicama ${ }^{19}$ Čunović ističe kako je u kreiranju programa za djecu i mlade potrebno dati prednost radionica-

${ }^{14}$ Usp. Špiranec, S. Nav. dj.

15 Usp. Špiranec, S.; J. Lasić-Lazić. Obrazovna uloga knjižnica: priprema građana za Europu znanja. // Vjesnik bibliotekara Hrvatske 48, 1(2005), 46-55. Dostupno i na: http://www.hkdrustvo. $\mathrm{hr} /$ datoteke/141/vbh/God.48 [citirano: 2014-02-17]. Kao jedini primjer informacijskog opismenjavanja koji se izrijekom temelji na elementima informacijske pismenosti navodi se Virtualna učionica NSK s osam modula i završnim ispitom za samoprocjenu znanja.

16 Usp. Špiranec, S.; M. Banek Zorica. Nav. dj.

Jednako je važna publikacija stranog autora u hrvatskom prijevodu: Lau, J. Smjernice za informacijsku pismenost u cjeloživotnom učenju. (Nav. dj.) Obje knjige, posebice tranzicijskim zemljama, mogu poslužiti kao poučna polazišna osnova za pronalaženje odgovarajućeg načina implementacije programa informacijske pismenosti. Nažalost, u Smjernicama nedostaje praktičnih primjera, a također je nedovoljno prepoznata uloga narodnih knjižnica.

17 Vidi časopis Svezak: 12, 12(2010). Dostupno i na: https://library.foi.hr/m3/kdc1.php?sqlnivo $=\&$ sqlid $=1 \& \mathrm{~B}=1 \&$ sqlx $=$ S02110\&broj $=201000012 \&$ volumen $=12 \& \mathrm{dlib}=\& \mathrm{~L}=\& \mathrm{~F}=\& \mathrm{vrsta}=\&$ gru$\mathrm{pa}=\& \mathrm{H}=\& \mathrm{U}=\&$ upit $=\& \mathrm{sc}=\& \mathrm{w}=1 \# \mathrm{vrh}[$ citirano 2018-05-30].

${ }_{18}$ Usp. Usp. Špiranec, S.; M. Banek Zorica. Informacijska pismenost? Da, mi to možemo... „Yes, we can“. // Svezak 12, 12(2010), 8-10. Dostupno i na: https://library.foi.hr/m3/pregled.asp $\mathrm{x} ? \mathrm{z}=100 \& \mathrm{zad}=\& \mathrm{sql}=\mathrm{SD} 2 \mathrm{CCD}(2 \mathrm{DCD}(\mathrm{DDDC} 2-\mathrm{DDD}-\mathrm{SSDDD} 8 \& \mathrm{od}=\& \mathrm{do}=\& \mathrm{~B}=1 \& \mathrm{vrsta}=\& \mathrm{gru}$ $\mathrm{pa}=\& \mathrm{H}=\& \mathrm{X}=\mathrm{S} 02110$ [citirano: 2018-05-30].

${ }_{19}$ Usp. Čunović, K. Poučavanje djece i mladih informacijskoj pismenosti u knjižnicama. // Svezak 12, 12(2010), 10-11. Dostupno i na: https://library.foi.hr/m3/pregled.aspx?z=100\&zad $=\& \mathrm{sql}=\mathrm{SD} 2 \mathrm{CCD}(2 \mathrm{DCD}(\mathrm{DDDC} 2-\mathrm{DDD}-\mathrm{SSDDCD} \& \mathrm{od}=\& \mathrm{do}=\& \mathrm{~B}=1 \& \mathrm{vrsta}=\&$ grupa $=\& \mathrm{H}=\& \mathrm{X}$ $=$ S02110 [citirano: 2018-05-30]. 
ma informacijskog opismenjavanja - kvalitetnoj pripremi za cjeloživotno učenje - navodeći radionicu Pretraživanje informacija na internetu (Knjižnica za mlade, Karlovac) te predlaže da se mladi uključe u sve etape nastanka programa. Ferenčić Martinčić u članku Zašto su knjižničari najvažniji ili o informacijskoj pismeno$s t i^{20}$ naglašava prednost knjižnica u informacijskom opismenjavanju korisnika pred ostalim srodnim ustanovama te to da se u narodnim knjižnicama u vidu sustavnih ili povremenih edukacija provode takvi programi. Primjerice u Gradskoj knjižnici Đurđevac učenicima se putem zabavnih i životnih primjera prezentiraju izvori informacija, njihova upotreba i vrednovanje. U članku Programi cjeloživotnog učenja u narodnim knjižnicama u jugozapadnoj Njemačkoj ${ }^{21}$ Sabolović-Krajina naglašava da se u Njemačkoj velika pozornost posvećuje animacijsko-obrazovnim programima s naglaskom na informatičkoj i informacijskoj pismenosti od rane dobi.

Povezanost informacijske pismenosti s narodnim knjižnicama donosi članak Knjižnične usluge za mlade: modeli i koncepti ${ }^{22}$ Stričević i Jelušića iz 2010. Opisuju se specifičnosti tzv. Google-generacije u informacijskom dobu i posljedice za knjižnice te se upućuje na novu ulogu knjižničara koji treba razvijati informacijsku pismenost mladih.

Nadalje objavljeni članci u domaćim znanstvenim časopisima (Vjesnik bibliotekara Hrvatske, Medijska istraživanja, Informatologija) na temu povezanosti informacijske pismenosti i knjižnica odnose se većinom na školske knjižnice i knjižnice u sustavu znanosti i visokog obrazovanja. Na temu istraživanja informacijske pismenosti vezano uz narodne knjižnice nema radova, ali postoji istraživanje vezano uz mlade korisnike vukovarskih knjižnica - narodnih i školskih. ${ }^{23}$ Nedostaje konkretnih istraživanja - ispitivanja vještine informacijske pismenosti, očito i zbog nedostatka nekomercijalnih standardiziranih instrumenata za provođenje takvih istraživanja. ${ }^{24}$ Također nema istraživanja na temu evaluacije programa informacijskog opismenjavanja.

\footnotetext{
${ }^{20}$ Usp. Ferenčić Martinčić, I. Zašto su knjižničari najvažniji ili o informacijskoj pismenosti. // Svezak 12, 12(2010), 11-12. Dostupno i na: https://library.foi.hr/m3/kdc1.php?sqlnivo=\&s qlid $=1 \& B=1 \&$ sqlx $=S 02110 \&$ broj $=201000012 \&$ volumen $=12 \& \mathrm{dlib}=\& \mathrm{~L}=\& \mathrm{~F}=\& \mathrm{vrsta}=\&$ gru$\mathrm{pa}=\& \mathrm{H}=\& \mathrm{U}=\& u p i \mathrm{t}=\& \mathrm{sc}=\& \mathrm{w}=1$ [citirano: 2018-05-30].

${ }^{21}$ Usp. Sabolović-Krajina, D. Programi cjeloživotnog učenja u narodnim knjižnicama u jugozapadnoj Njemačkoj. // Svezak 12, 12(2010), 73-74. Dostupno i na: https://library.foi.hr/m3/pregled.aspx? $\mathrm{z}=100 \& \mathrm{zad}=\& \mathrm{sql}=\mathrm{SD} 2 \mathrm{CCD}(2 \mathrm{DCD}(\mathrm{DDDC} 2-\mathrm{DDD}-\mathrm{SSDD} 73 \& \mathrm{od}=\& \mathrm{do}=\& \mathrm{~B}=1 \& \mathrm{vr}-$ $\mathrm{sta}=\&$ grupa $=\& \mathrm{H}=\& \mathrm{X}=\mathrm{S} 02110$ [citirano: 2018-05-30].

${ }^{22}$ Usp. Stričević, I.; S. Jelušić. Knjižnične usluge za mlade: modeli i koncepti. // Vjesnik bibliotekara Hrvatske 53, 1(2010), 14-17. Dostupno i na: https://www.hkdrustvo.hr/vjesnik-bibliotekara-hrvatske/index.php/vbh/article/view/443/438 [citirano 2018-05-31].

${ }^{23}$ Radi se o članku Baier Jakovac, A.; I. Hebrang Grgić. Informacijska (ne)pismenost: istraživanje mladih korisnika knjižnica u Vukovaru. // Knjižničarstvo 19, 1-2(2015), 27-46. Dostupno i na: http://bib.irb.hr/datoteka/801946.247_Baier-Jakovac_Hebrang-Grgic_2015_1-2.pdf. Prikaz članka slijedi u nastavku teksta.

${ }^{24}$ Usp. Jokić, A.; D. Koljenik; S. Faletar Tanacković; B. Badurina. Nav. dj., str. 74.
} 
U članku iz 2015. pod naslovom Informacijska (ne)pismenost: istraživanje mladih korisnika knjižnica u Vukovaru ${ }^{25}$ Baier Jakovac i Hebrang Grgić opisuju rezultate istraživanja provedenog na učenicima osnovnih i srednjih škola s ciljem istraživanja poznavanja digitalnih zbirki i obrazovnih sadržaja u Hrvatskoj i svijetu te načina njihova korištenja. Zaključeno je da se ne organizira dovoljno aktivnosti za razvoj informacijske pismenosti, da se mladi nedovoljno informiraju o digitalno dostupnim izvorima, a najviše koriste Wikipediju i e-lektire. Bolja informacijska pismenost može se ostvariti ciljanim programskim aktivnostima sa sadržajima digitalno dostupnog znanja i uz suvremenu i zanimljivu tehnologiju.

U radu Informacijsko opismenjavanje u narodnim knjižnicama ${ }^{26}$ iz 2016. Stipetić Šušak objašnjava pojam i koncept informacijske pismenosti te njegovu primjenu u knjižnicama, opisuje modele opismenjavanja i načine njegova provođenja u praksi.

Stručni skup Informacijska pismenost u dječjim knjižnicama ${ }^{27}$ organiziran je u Zagrebu 2017. godine. U programskoj najavi skupa bilo je istaknuto da će se on baviti teorijskim postavkama i praktičnim metodama informacijskog opismenjavanja djece i mladih. Broj prijavljenih izlaganja dobre prakse dokazuje da se u desetogodišnjem razdoblju od izdavanja prvog priručnika o informacijskoj pismenosti u RH profilirao određeni broj knjižnica koje aktivno provode programe informacijske pismenosti, najčešće kao djelatnost dječjih odjela. Skup je imao namjeru obuhvatiti širi rakurs te je uz sedam izlagača iz narodnih knjižnica uključio i tri školska knjižničara. Predstavljeni programi informacijskog opismenjavanja primarno su se bavili znanjem i vještinama potrebnim za razumijevanje i uporabu informacija, kao i vrijednosnim sudovima prema informacijama, s manjim naglaskom na disciplinarnoj usmjerenosti, što je, kako navode Špiranec i Banek Zorica, poželjno za ranije faze obuke ili niže razrede škole. ${ }^{28}$ Također, pokazalo se da se među knjižničarima i nastavnicima počinje izgrađivati svijest o potrebi za informacijskom pismenošću.

\section{Program Informacijsko opismenjavanje tinejdžera u Gradskoj knjižnici Zadar}

\subsection{Nastanak i koncept}

U Gradskoj knjižnici Zadar 2015. godine pokrenuta je inicijativa osmišljavanja novog programa s ciljem poučavanja informacijskoj pismenosti. Pristupilo se izradi plana s nazivom Informacijsko opismenjavanje tinejdžera, kojim se Knjižnica

\footnotetext{
${ }_{25}$ Usp. Baier Jakovac, A.; I. Hebrang Grgić. Nav. dj.

${ }^{26}$ Usp. Stipetić Šušak, J. Informacijsko opismenjavanje u narodnim knjižnicama. // Vjesnik Bibliotekara Hrvatske 59, 3-4(2016), str. 100. Dostupno i na: https://www.hkdrustvo.hr/vjesnik-bibliotekara-hrvatske/index.php/vbh/article/view/502/474 [citirano: 2018-05-10].

${ }_{27}$ Hrvatsko knjižničarsko društvu. Informacijska pismenost u dječjim knjižnicama. [citirano: 2018-03-15]. Dostupno na: https://www.hkdrustvo.hr/hr/skupovi/skup/316/.

${ }^{28}$ Usp. Špiranec, S.; M. Banek Zorica. Nav. dj., str. 127.
} 
prijavila na Poziv za predlaganje Programa javnih potreba u kulturi Grada Zadra za 2016. godinu. Program je ušao u Plan i program rada za 2016. godinu ${ }^{29} \mathrm{Grad}-$ ske knjižnice Zadar i od tada je sastavni dio njezina strateškog dokumenta. Na temelju inicijalnog dokumenta u Gradskoj knjižnici Zadar pristupilo se detaljnoj razradi koncepcije programa na sadržajnoj i metodičkoj razini ${ }^{30} \mathrm{i}$ razvijala se promidžbena aktivnost. Provođenje programa započelo je u prosincu 2016. godine i do 26. ožujka 2018. održano je dvadeset radionica s 419 učenika. Program je predstavljen izlaganjem Prvi link nije uvijek najbolji! na stručnom skupu Informacijska pismenost u dječjim knjižnicama (2017.) te u sklopu programa Informacijska $i$ medijska pismenost - strategija prakse za ugled namijenjenog knjižničarima Crne Gore prilikom posjeta zadarskim knjižnicama i Sveučilištu u Zadru 2017. godine.

Cilj je programa razvijanje sposobnosti učinkovitog pronalaženja, korištenja i vrednovanja internetskih izvora i informacija te razvijanje knjižnične pismenosti korištenjem kataloga knjižnice.

Program se temelji na principu otvorenosti i fleksibilnosti u različitim aspektima, primjerice korisničkim skupinama (namijenjen je učenicima viših razreda osnovne škole, učenicima srednjih škola, ali i svim zainteresiranim pojedincima ili skupinama), mjestu održavanja (narodne i školske knjižnice, škole, grad Zadar, mjesta Zadarske županije), sadržaju (koji je definiran, ali se može prilagoditi korisničkim skupinama) i voditeljima (tri knjižničarke provodile su program, najčešće dvije po radionici kako bi se održala dinamika 45-minutne prezentacije).

Različite usluge informacijskog opismenjavanja mogu se prema Hadengue podijeliti u tri osnovne kategorije: vođena razgledavanja knjižnica - knjižnična pismenost, tečajevi i specifična pomoć - vodiči za korisnike (online ili tiskani). ${ }^{31}$ Premda se ovdje radi o uslugama informacijskog opismenjavanja za visokoškolske knjižnice, univerzalnost kategorija potaknula je djelatnike na prilagodbu i primjenu u narodnoj knjižnici te su sve tri kategorije integrirane u program Gradske knjižnice Zadar. Vođenje i upoznavanje učenika s prostorom knjižnice prakticiralo se i izvan programa, a sada se, s naglaskom na obilasku studijske čitaonice i referentne zbirke, integriralo u jednu od kategorija programa. Kroz radionicu polaznici se upoznaju s kriterijima vrednovanja internetskih stranica i sadržaja stranice te s kvalitetnim i korisnim mrežnim stranicama, demonstriraju se tehnike pretraživanja i upućuje ih se na pretraži-

${ }_{29}$ Usp. Gradska knjižnica Zadar. Plan i program rada za 2016. [citirano: 2018-02-05] . Dostupno na: http://www.gkzd.hr/sites/default/files/Plan\%20i\%20program\%20gkzd\%202016_scan.pdf.

${ }^{30}$ Obuhvaćene su dvije razine pripreme sukladno preporukama. Usp. isto. Str. 160.

${ }^{31}$ Usp. Hadengue, V. What can e-learning do for university libraries? // Library Review 53, 8(2004), 397. DOI: https://doi.org/10.1108/00242530410556229 . Citirano prema: Rubinić, D.; I. Stričević. Visokoškolska knjižnica u programima informacijskog opismenjavanja studenata : istraživanje programa Sveučilišne knjižnice Sveučilišta Karl-Franzens Graz // Vjesnik bibliotekara Hrvatske 54, 4(2011), 27. Dostupno i na: https://www.hkdrustvo.hr/vjesnik-bibliotekara-hrvatske/index.php/vbh/article/view/338/333 [citirano: 2018-02-22]. 
vanje knjižničnog kataloga. Na kraju radionice, kao oblik pomoći i podsjetnik, dijele se letci: vodič kroz ključne točke predavanja (tehnike pretraživanja i korisne poveznice) i letak s informacijama o Gradskoj knjižnici Zadar, a kao vid ponavljanja odigran je i Kahoot-kviz. ${ }^{32}$ Opisani elementi ujedno čine sadržajnu razinu programa, koja je općeg i generičkog karaktera, primjereno nižim stupnjevima u obrazovanju. ${ }^{33}$

Kako bi se sadržaj predstavio na što primjereniji način, imajući u vidu učeničku populaciju, prilikom pripreme programa vodilo se računa o njegovoj metodičkoj razini. Na početku radionice primjenjuje se metoda kratkog usmenog izlaganja, a poštujući pravilo da ,predavački tip nastave nije pogodan za stjecanje određenih vještina (tehničkih i mentalnih) ${ }^{\text {‘34 }}$, koristi se metoda razgovora s učenicima. Također, prisutni su i vježbanje (osobito aktivno uključivanje učenika prilikom vježbanja pretraživanja) i ponavljanje sadržaja putem kviza, sve uz korištenje informacijsko-komunikacijske tehnologije. U izlaganju sadržaja primijenjeni su didaktički principi nastavnog procesa - sistematičnost i postupnost (iskazana pravilima: od lakšeg prema težem, od jednostavnog prema složenom, od poznatog prema nepoznatom), a osobito princip primjerenosti sadržaja dobi, stupnju obrazovanja i iskazanoj zainteresiranosti učenika. ${ }^{35}$

\subsection{Promidžbene aktivnosti}

Dvojaka je uloga koju Gradska knjižnica Zadar ostvaruje provođenjem programa Informacijsko opismenjavanje tinejdžera. Mladima se kao korisničkoj skupini nudi novi program koji im može približiti knjižnične usluge i privući ih da se češće, intenzivnije i učinkovitije koriste knjižnicom, ali i informacijama izvan knjižnice. Knjižnici se pruža prilika da bolje pozicionira svoju ulogu u lokalnoj zajednici kroz suradnju s odgojno-obrazovnim ustanovama te unaprijedi usluge putem međuinstitucionalne suradnje.

Zbog tradicionalne podjele knjižnica na odjele za odrasle i dječje odjele, usluge i aktivnosti za mlade često su se vezale upravo uz dječje odjele. Pojava novih tehnologija, brze promjene koje su zavladale i zahtjevi za novim vrstama pismenosti utjecali su i na odnos knjižnica prema mladima te su se mladi istaknuli kao

\footnotetext{
32 Više informacija o Kahoot-kvizu općenito vidi u Belevski, M.; S. Segarić. iPad i u našoj školiIpad in Our School // Stručni skup Dječja knjižnica danas i njezina odgojno obrazovna dimenzija : zbornik radova / uredili Marina Simić i Vilijam Lakić. Šibenik : Gradska Knjižnica Juraj Šižgorić, 2017. Str. 68-69.

33 Usp. Špiranec, S.; M. Banek Zorica. Nav. dj., str. 162.

${ }^{34}$ Rubinić, D.; I. Stričević. Nav. dj., str. 40.

35 O principima u nastavi vidi: Poljak, V. Didaktika. 9. izd. Zagreb : Školska knjiga, 1991. Str. 199-219.
} 
zasebna korisnička skupina na koju treba obratiti pažnju. ${ }^{36}$ Sudionicima programa Informacijsko opismenjavanje tinejdžera želi se pokazati da korištenjem usluga Knjižnice mogu steći kompetencije informacijske pismenosti te da im knjižnice mogu pomoći u korištenju izvora informacija bez obzira na to gdje se oni nalaze, čime se želi ukazati na pozitivne aspekte usvajanja navedenih znanja. Gradska knjižnica Zadar putem programa ostvaruje suradnju s ustanovama u okruženju kojoj su prethodile različite promidžbene aktivnosti. Ciljna su skupina učenici, nastavnici i školski knjižničari, a kako bi se nazivom približilo mladima, odabran je i promidžbeni naziv - Googlaj, ali pametno - prvi link nije uvijek najbolji!, što se smatralo marketinški ispravnim korakom u stvaranju imidža. Knjižnica je neprofitna ustanova te je cilj marketinških aktivnosti koje provodi ostvarivanje koristi za zajednicu, a sve aktivnosti koje se provode pozitivno djeluju na planiranje, provedbu i djelovanje koje ustanova ostvaruje. ${ }^{37}$ Kvalitetna i uspješna promidžba podrazumijevala je korištenje različitih elemenata marketinške komunikacije. ${ }^{38}$ Program se oglašavao putem mrežne stranice Knjižnice, promidžbenih plakata, citylight plakata i letaka, kao i preko medija masovne komunikacije na lokalnoj razini. Koristio se i izravni marketing koji pretpostavlja orijentaciju na pojedinca, pa su tako ravnateljima osnovnih i srednjih škola u Zadru i Zadarskoj županiji poslani službeni dopisi o pokretanju novog programa Gradske knjižnice Zadar. ${ }^{39}$ Svim navedenim aktivnostima nastojalo se doći do ciljne skupine i popularizirati ponuđenu aktivnost, imajući u vidu kako postoji mogućnost nepoznavanja značenja pojma informacijska pismenost, što je kao mogući problem u informacijskom opismenjavanju opisano u literaturi. ${ }^{40}$ Školskim knjižničarima želi se pokazati da ta vrsta usluge otvara knjižnicu prema korisnicima te da informacijska pismenost donosi stvarne rezultate i utječe na ishode učenja. Nastavnicima se informacijska pismenost želi prikazati kao program koji će pomoći učenicima u učenju te rješavanju i pisanju njihovih zadaća. Učenicima se želi približiti ideja da će uspješnije i brže rješavati svoje zadaće koje uključuju pronalaženje i korištenje informacija i informacijskih izvora.

Provođenjem programa Gradska knjižnica Zadar ostvarila je međuinstitucionalnu suradnju, što je rezultiralo umreženošću u zajednici unutar koje djeluje. Sve to pomaže Knjižnici da se još bolje pozicionira i bude vidljivija, što se smatra neminovnim za buduće djelovanje svih informacijskih i baštinskih ustanova.

\footnotetext{
${ }^{36}$ Usp. Aparac-Jelušić,T., M. Kasap. Izazovi knjižnične arhitekture za mlade. // Vjesnik bibliotekara Hrvatske 60, 2-3(2017), 156. Dostupno i na: https://www.hkdrustvo.hr/vjesnik-bibliotekara-hrvatske/index.php/vbh/article/view/581/533 [citirano: 2018-03-16].

${ }_{37}$ Usp. Pavičić, J. Strategija marketinga neprofitnih organizacija. Zagreb: Masmedia, 2003. Str. 31.

${ }^{38}$ Usp. Pavičić, J.; N. Alfirević; Lj. Aleksić. Marketing i menadžment u kulturi i umjetnosti. Zagreb: Masmedia, 2006. Str. 191.

39 Usp. isto, str. 197.

40 Usp. Špiranec, S.; M. Banek Zorica. Nav. dj., str. 176.
} 


\section{Istraživanje}

\subsection{Cilj istraživanja}

Cilj je istraživanja dobiti pokazatelje o programu Informacijsko opismenjavanje tinejdžera koji mogu poslužiti u njegovu vrednovanju i unapređivanju. Istraživanjem se primarno željelo doznati mišljenje i odrediti stupanj zadovoljstva učenika osnovnih i srednjih škola ključnim aspektima edukacije: jasnoćom, razumljivošću, korisnošću i zanimljivošću prezentiranog sadržaja te korištenjem knjižnice i kataloga. Također se željelo saznati razlikuju li se u mišljenju o navedenim aspektima učenici osnovnih i srednjih škola.

\subsection{Metodologija istraživanja}

Istraživanje je provedeno u razdoblju od travnja do studenog 2017. godine među učenicima sedmih i osmih razreda osnovnih škola te učenicima srednjih škola grada Zadra i Zadarske županije koji su sudjelovali u programu. Anketirani uzorak čini 201 polaznik radionice.

Podaci su prikupljeni anonimnom anketom (prilog 1), uvažavajući pritom načela Etičkog kodeksa istraživanja s djecom. ${ }^{41}$ Anonimna anketa odabrana je zbog svoje pouzdanosti, jer se pretpostavljalo da će ispitanici biti iskreniji u davanju odgovora. Anketa je također odabrana i zbog ekonomičnosti - u kratkom vremenu omogućuje prikupljanje podataka dobivenih od većeg broja ispitanika.

Anketni upitnik za učenike podijeljen je u tri dijela. Prvi dio čine dva zatvorena dihotomna pitanja. Drugi dio anketnog upitnika sastoji se od pet pitanja, također zatvorenog tipa, ali s ponuđenom ljestvicom intenziteta, sastavljenom po načelu Likertove ljestvice stavova ${ }^{42} \mathrm{~s}$ pet stupnjeva zbog primjerenosti školskom uzrastu anketiranog uzorka, odnosno zbog bliskosti sa školskim sustavom ocjenjivanja od 1 do 5 .

Kako bi učenici mogli slobodnije iznijeti mišljenja i primjedbe, treći dio anketnog upitnika sastoji se od dva pitanja otvorenog tipa.

\subsection{Prikaz rezultata i rasprava}

Istraživanje je provedeno tijekom deset održanih radionica informacijskog opismenjavanja među učenicima triju razreda osnovne škole i osam razreda srednje

${ }^{41}$ Usp. Etički kodeks istraživanja s djecom / urednici Marina Ajduković, Vladimir Kolesarić. Zagreb : Državni zavod za zaštitu obitelji, materinstva i mladeži : Vijeće za djecu Vlade Republike Hrvatske, 2003. [citirano: 2018-03-07]. Dostupno na: http://www.ufzg.unizg.hr/wp-content/ uploads/2013/12/Eticki-kodeks-istrazivanja-s-djecom.pdf.

${ }^{42}$ Usp. Cohen, L.; L. Manion; K. Morrison. Metode istraživanja u obrazovanju. Jastrebarsko : Naklada Slap, 2007. Str. 253. 
škole. Ukupno je ispitan 201 učenik, od toga 59 učenika iz osnovnih škola i 142 učenika iz srednjih škola.

\section{Anketni upitnik - učenici}

Korištenje usluga Knjižnice

Na prvo pitanje, koje se odnosi na korištenje usluga Gradske knjižnice Zadar (slika 1), veći dio učenika osnovne $(67,8 \%)$ i srednje škole $(76,8 \%)$ odgovorio je da je do sada koristio usluge Knjižnice. Manji broj učenika iz osnovne (32,2 \%) i srednje škole $(23,2 \%)$ do sada nije koristio usluge koje Knjižnica pruža. Dobiveni rezultati pokazuju da više od dvije trećine učenika osnovnih i srednjih škola koristi usluge Knjižnice, što ujedno implicira da su članovi Knjižnice.

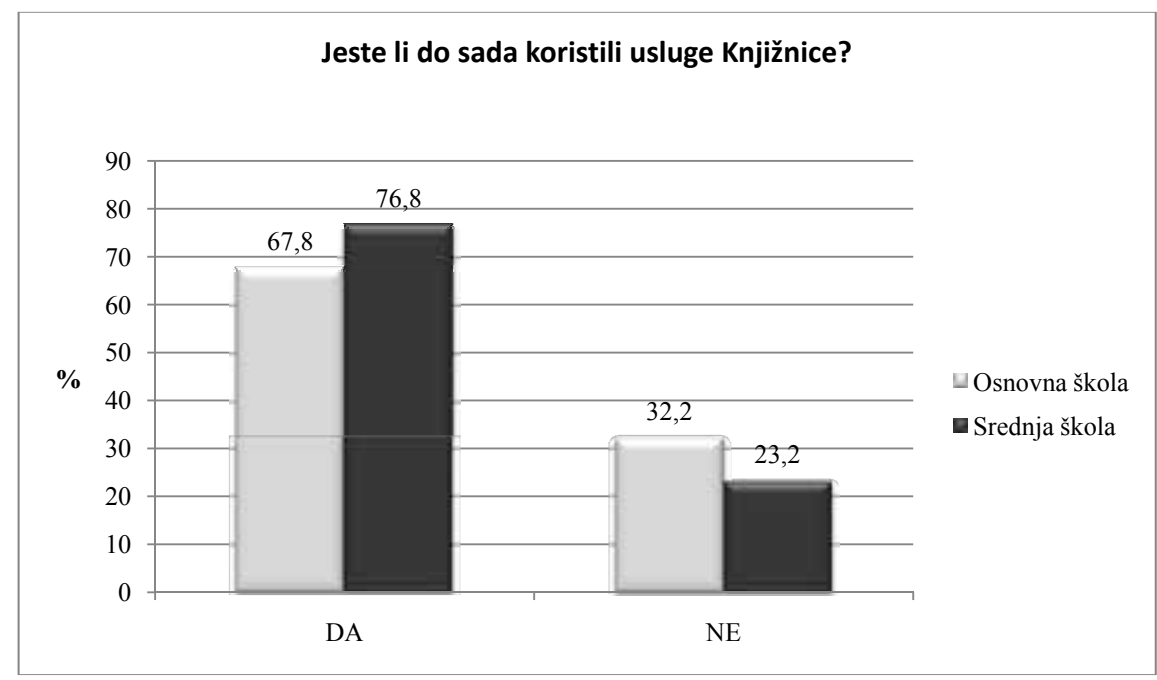

Slika 1. Korištenje usluga Knjižnice

\section{Korištenje online kataloga Knjižnice}

Drugim pitanjem željelo se saznati koriste li učenici online katalog, kako bi se dobio uvid u to koliko je na radionicama pažnje potrebno posvetiti tom segmentu, odnosno usmjeriti se na određene oblike pretraživanja (slika 2). Samo 10,2\% učenika osnovne i 10,6 \% učenika srednje škole odgovorilo je da koristi online katalog, dok ga čak 89,8 \% učenika osnovne i 89,4 \% učenika srednje škole ne koristi. Očit je nerazmjer između upisanih članova Knjižnice i korištenja kataloga na razini cijelog uzorka. 


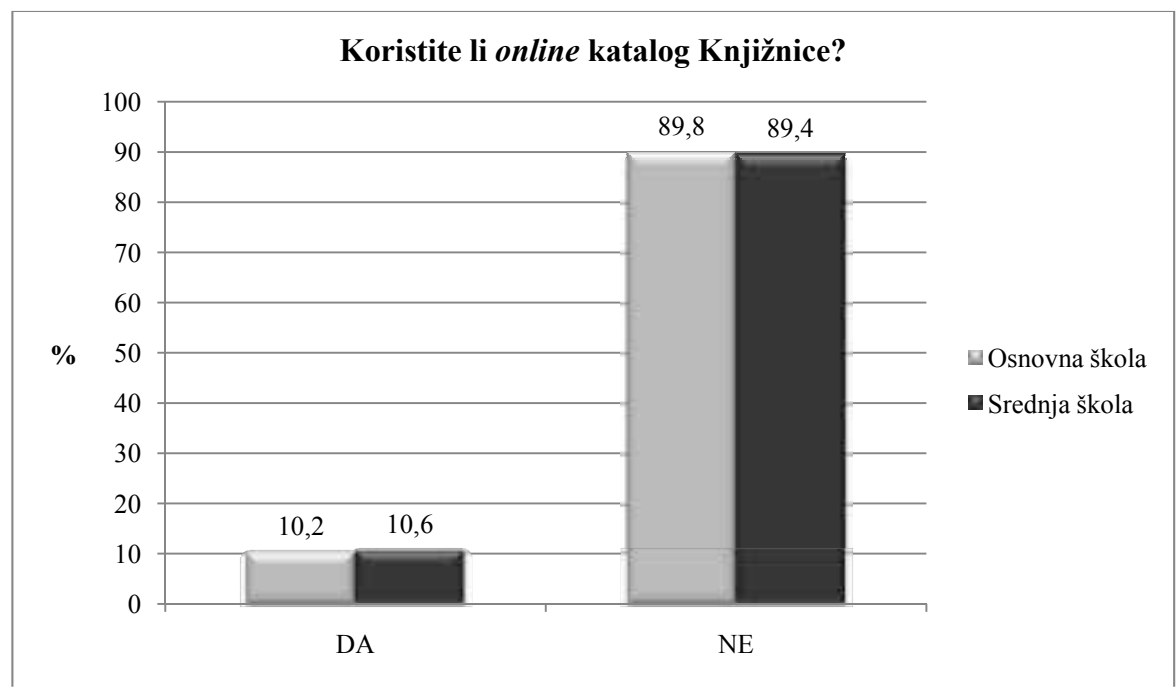

Slika 2. Korištenje online kataloga Knjižnice

\section{Zanimljivost teme radionice}

Anketni se upitnik nadalje sastojao od pet pitanja zatvorenog tipa s mogućnošću ocjene intenziteta.

Prvim pitanjem željelo se saznati kako učenici ocjenjuju zanimljivost teme radionice (slika 3). Od 59 učenika osnovne škole njih 10,2 \% zanimljivost teme radionice ocijenilo je ocjenom 1 (nedovoljan), 11,9\% učenika ocjenom 2 (dovoljan), $20,3 \%$ ocjenom 3 (dobar), 37,3\% ocjenom 4 (vrlo dobar), a 20,3\% ocjenom 5 (odličan).

Među učenicima srednjih škola njih 5,6 \% ocijenilo je zanimljivost radionice ocjenom nedovoljan (1) i dovoljan (2). Nešto više učenika, odnosno njih $27,5 \%$, ocijenilo je zanimljivost radionice ocjenom dobar (3), a najviše učenika, njih 42,3 $\%$, ocjenom 4. Najvišom je ocjenom (5) zanimljivost programa ocijenilo 19,0 \% učenika.

Iz grafičkog prikaza vidljivo je da su osnovnoškolci u dvostruko većem postotku ocijenili zanimljivost teme radionice nižim ocjenama (nedovoljan i dovoljan), dok je srednjoškolcima zanimljivost teme radionice bila uglavnom vrlo dobra i dobra. No s obzirom na to da je više od polovice učenika osnovnih i srednjih škola zanimljivost programa ocijenilo ocjenama 4 i 5 , može se zaključiti da je većini učenika tema radionice bila zanimljiva. 


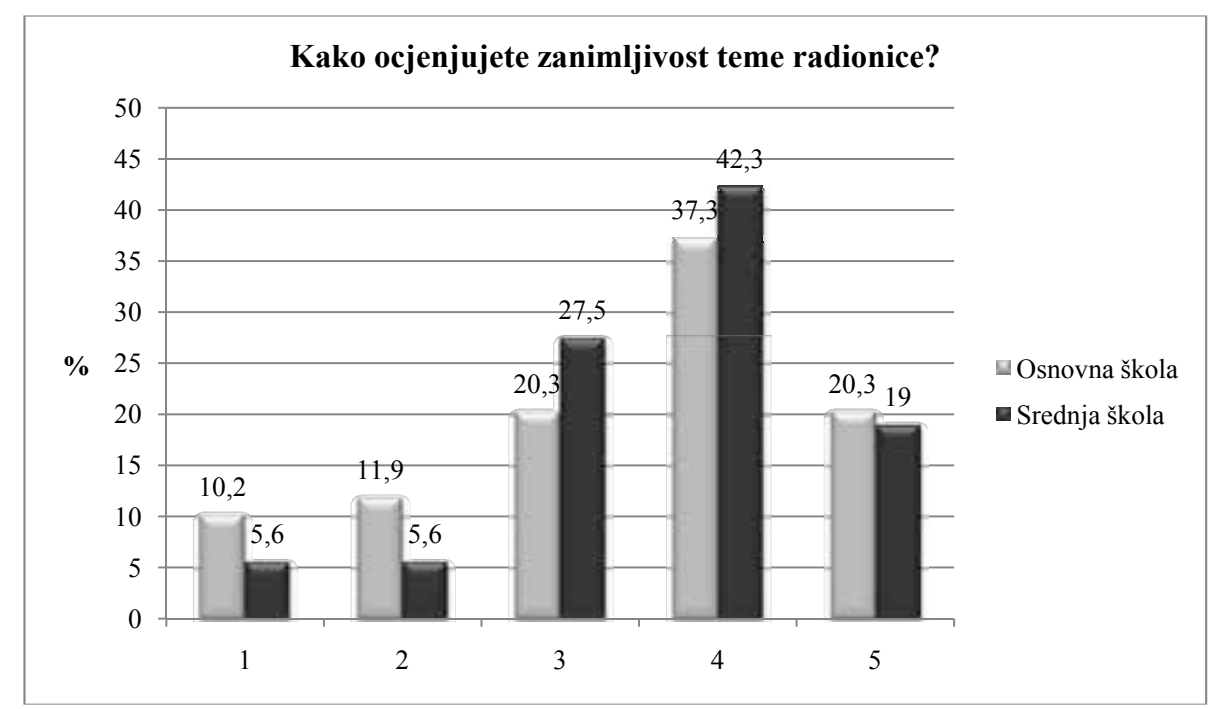

Slika 3. Zanimljivost teme radionice

\section{Jasnoća i razumljivost sadržaja radionice}

Odgovori na drugo pitanje u ocjenama po skali pokazali su koliko je jasno i razumljivo prezentiran sadržaj radionice (slika 4). Među svim pitanjima zatvorenog tipa, ovdje se najmanji broj učenika odlučio za niže ocjene. Samo 3,4 \% učenika osnovnih škola i 3,5 \% učenika srednje škole jasnoću i razumljivost radionice ocijenili su nedovoljnim, a 5,1 \% učenika osnovne i $2,1 \%$ učenika srednje škole ocjenom dovoljan (2). Učenici osnovne škole ocjenjivali su jasnoću sadržaja radionice ocjenom dobar (3) čak triput češće od srednjoškolaca (22,0 \% osnovnoškolaca naprama 7,0 \% srednjoškolaca). Sadržaj je vrlo jasan za $39 \%$ učenika osnovnih škola i $28,2 \%$ učenika srednjih škola, a odlično razumljiv za $30,5 \%$ osnovnoškolaca i 59,2 \% srednjoškolaca.

Iz rezultata je vidljivo da je sadržaj radionice jasniji i razumljiviji učenicima srednjih škola, a nešto manje jasan učenicima osnovnih škola. Dobiveni podaci mogu biti rezultat zahtjevnosti prezentiranog sadržaja za tu dob, premda se sadržaj prezentacije prilagođava uzrastu. Navedeno ukazuje na potrebu dodatne prilagodbe sadržaja i metoda rada kako bi obrazovni sadržaji bili razumljiviji i mlađim učenicima. 


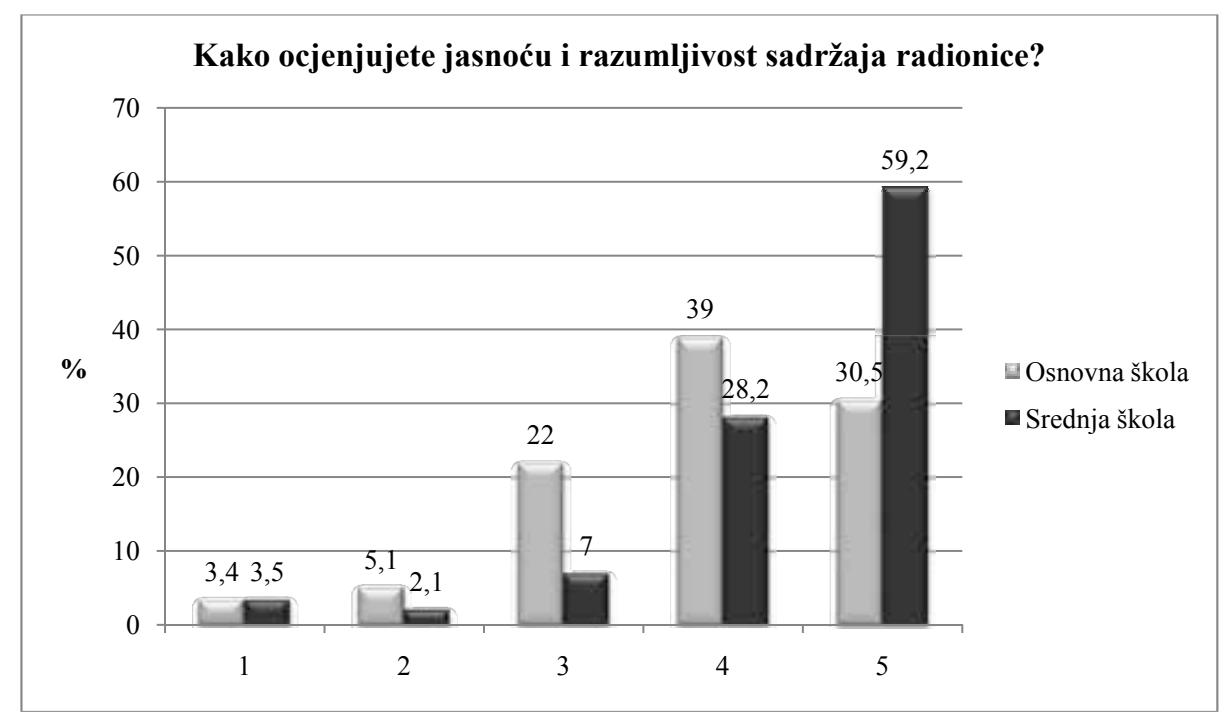

Slika 4. Jasnoća i razumljivost sadržaja radionice

\section{Stjecanje novog znanja}

Sljedećim pitanjem dobiveni su podaci o percepciji stjecanja novog znanja na radionici (slika 5). Manji dio srednjoškolaca (6,3 \% učenika) nego osnovnoškolaca $(11,9 \%)$ smatra da nije naučio ništa novo. Ocjenom dovoljan stjecanje novog znanja ocijenilo je 10,2 \% osnovnoškolaca i 3,5 \% srednjoškolaca. Ocjenom dobar stjecanje novog znanja ocijenilo je 16,9 \% učenika osnovne škole i 14,1 \% učenika srednjih škola. Približno jednak dio učenika osnovnih (28,8 \%) i srednjih (26,8 \%) škola stjecanje novog znanja ocijenio je ocjenom vrlo dobar (4). Odličnim je stjecanje novog znanja ocijenilo 49,3 \% učenika srednjih škola i tek 32,2 \% učenika osnovnih škola.

Iz rezultata je vidljivo da učenici srednjih škola u većom postotku smatraju da su na radionici stekli novo znanje te su se u znatno manjem postotku od učenika osnovnih škola izjasnili da su stekli nedovoljno (1) i dovoljno (2) novog znanja. Uzimajući u obzir odgovore učenika osnovne škole na prethodno pitanje, njihovo izjašnjavanje o nedovoljnom stjecanju novog znanja može biti posljedica nejasnoće prezentiranog sadržaja. Činjenica da učenici osnovnih i srednjih škola u većem postotku ipak smatraju da su stekli novo znanje pokazuje da im je prezentirano znanje do sada bilo nepoznato. 


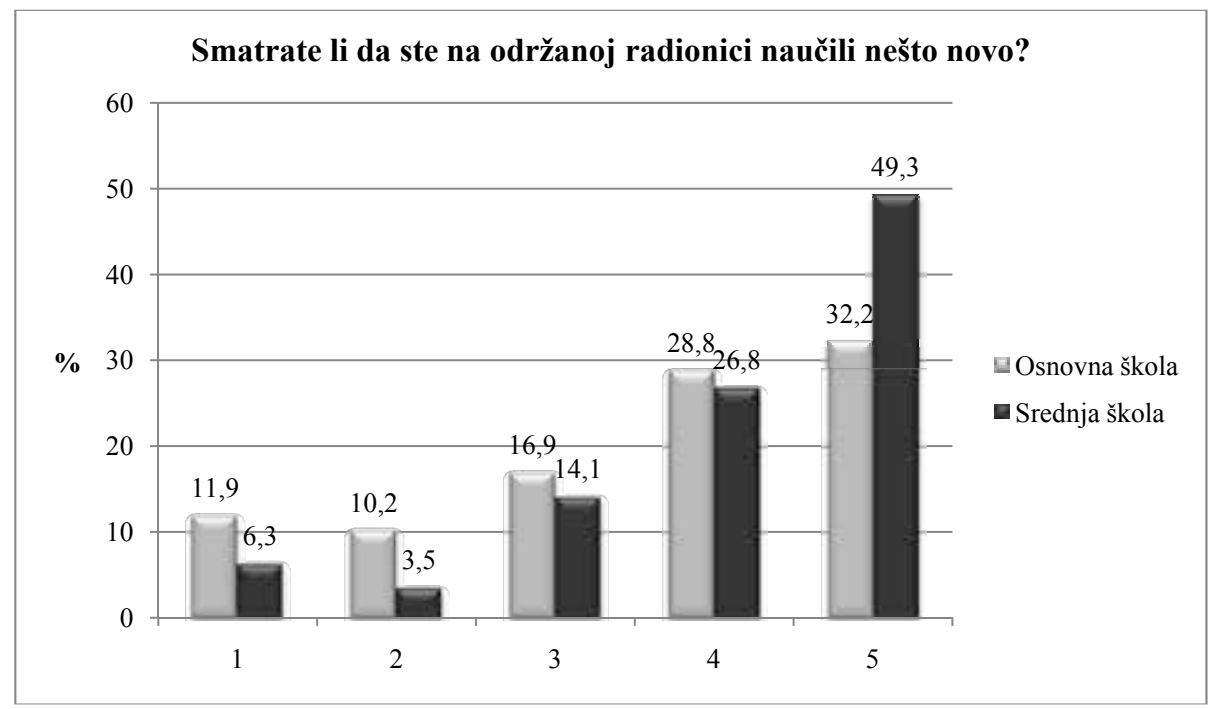

Slika 5. Stjecanje novog znanja

\section{Korisnost novostečenog znanja}

Posljednjim pitanjem s ocjenama na skali nastojalo se saznati smatraju li učenici da će im novostečeno znanje koristiti u daljnjem učenju i školovanju (slika 6).

Među učenicima osnovne škole njih 15,3 \% odgovorilo je da im novostečeno znanje neće koristiti, dok manji postotak učenika srednje škole, odnosno njih 8,5 $\%$, smatra isto. Da će im novostečeno znanje biti dovoljno korisno, smatra $22 \%$ učenika osnovne škole i nešto manje srednjoškolaca, odnosno njih $8,5 \%$. Da će im znanje stečeno na radionici dobro poslužiti smatra $18,6 \%$ učenika osnovne i 16,2 $\%$ učenika srednje škole. Novostečeno će znanje moći vrlo dobro iskoristiti $22 \%$ osnovnoškolaca i $36,6 \%$ srednjoškolaca, a odlično će ga upotrijebiti $22 \%$ učenika osnovne škole i 30,3\% učenika srednje škole.

Među dobivenim je rezultatima kod osnovnoškolaca uočljivo da je raspon postotka u ocjenjivanju približno sličan (od 15 do $22 \%$ ), tj. da nema velikih oscilacija, dok su srednjoškolci u većem postotku izrazili korisnost novog sadržaja, što može biti pokazatelj boljeg razumijevanja prezentiranog sadržaja, pa se lakše percipira i njegova primjenjivost, odnosno korisnost. 


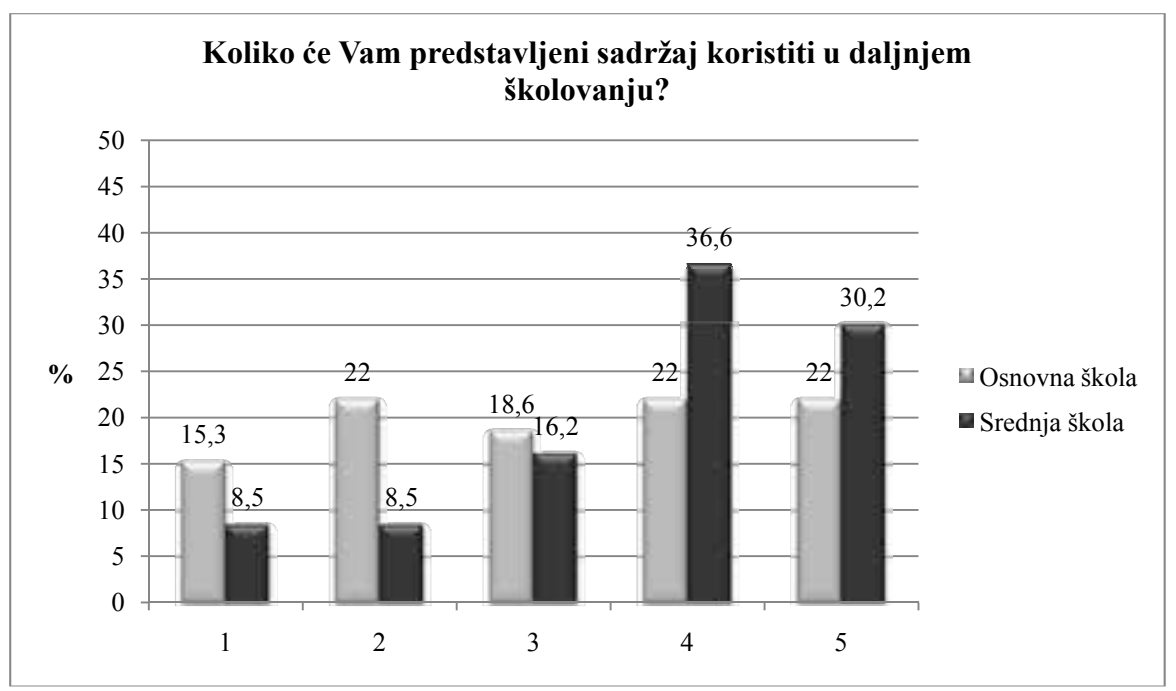

Slika 6. Korisnost novostečenog znanja

\section{Najkorisniji dio radionice}

Pitanje o najkorisnijem dijelu radionice bilo je otvorenog tipa (slika 7).

Od ukupno 59 učenika osnovnih škola, na to pitanje odgovorilo je 50,8 \% učenika. Od toga se njih 26,7 \% odlučilo za dio u kojem se prezentira napredno pretraživanje tražilice Google, a 23,3 \% za relevantne internetske stranice. Za 16,7 \% učenika najkorisniji je kviz u kojem se ponavlja gradivo radionice, a za 13,3 \% učenika pretraživanje online kataloga. Da im nije koristan nijedan dio radionice, smatra 13,3 \% učenika, dok njih 6,7 \% smatra da im je sve bilo korisno. Od ukupno 142 učenika srednjih škola, njih 67,6 \% odgovorilo je na ovo pitanje. U 42,7 \% slučajeva napredno pretraživanje prepoznato je kao najkorisniji dio radionice, relevantne internetske stranice najkorisnije su za $28,1 \%$ učenika, dok $11,5 \%$ učenika smatra da su to tehnike pretraživanja. Za 5,2 \% učenika najkorisnijim se pokazalo pretraživanje online kataloga, dok njih 12,5 \% smatra da im je sve korisno.

Može se zaključiti da su napredno pretraživanje i relevantne internetske stranice kategorije koje su se učenicima pokazale najkorisnijima. To su ujedno sadržaji $\mathrm{s}$ kojima se do sudjelovanja u radionicama nisu susretali. Zanimljivo je da srednjoškolci kviz nisu ocijenili korisnim te da nisu odabirali ponuđeni odgovor prema kojem nijedan dio radionice nije bio koristan. 


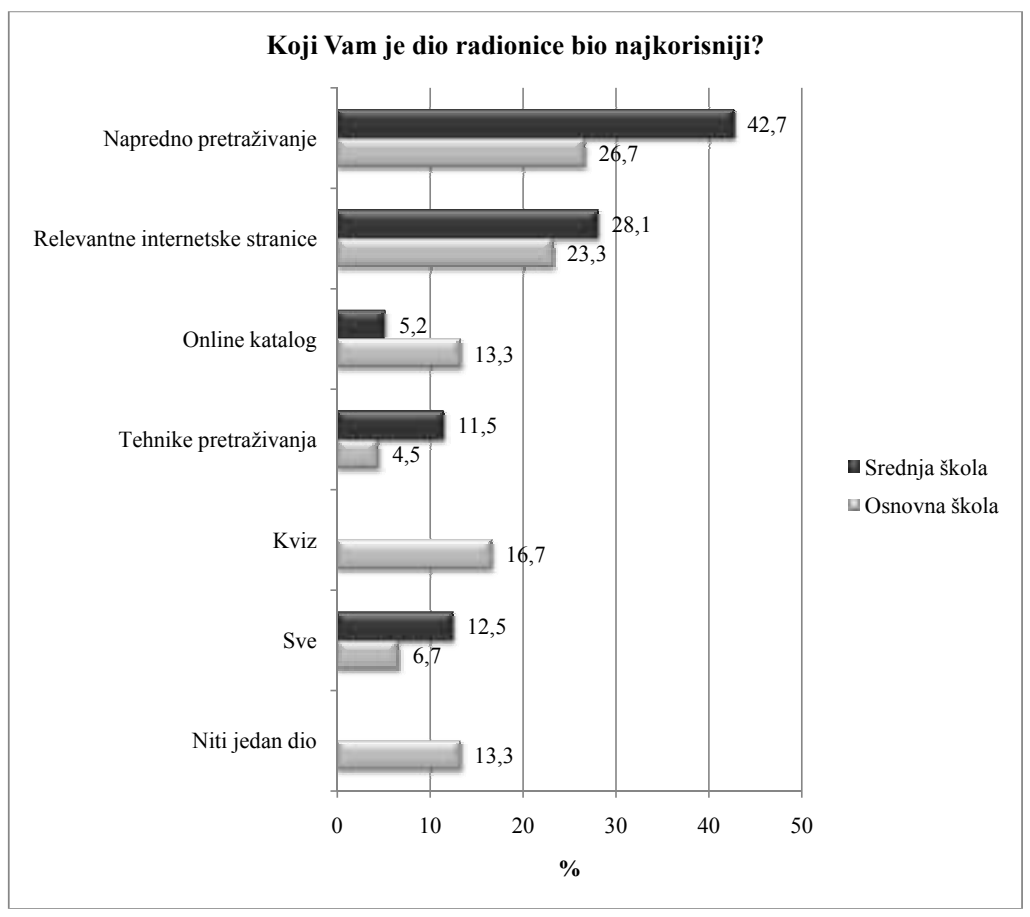

Slika 7. Najkorisniji dio predavanja

\section{Komentari učenika}

U posljednjem pitanju, koje je bilo otvorenog tipa, učenici su mogli napisati svoje komentare. Od ukupno 59 učenika osnovne škole, njih 40,7 \% komentiralo je radionicu, dok je od ukupno 142 učenika srednje škole to učinilo njih $43 \%$. Osim pet negativnih komentara (nije bilo dovoljno glasno, nije mi koristilo, dosadno, nije bilo zanimljivo, može i bolje), ostali komentari bili su pozitivni (prezadovoljna sam jer sam naučila pametno guglati, predavanje je bilo vrlo zanimljivo iako se na prvu nije činilo, izvrsna prezentacija - nadam se još ovakvih, vrlo dobro, smatram da sam uz pomoć ovog programa dosta naučila, bili ste dobri, bilo je super, odlično, zabavno, predavanje je bilo korisno i zanimljivo, sve pet, simpa voditeljice...). Velik postotak pozitivnih komentara pokazatelj je kako zanimljivosti radionice tako i njezine korisnosti za učeničku populaciju.

\subsection{Zaključno o istraživanju}

Istraživanje je pokazalo da većina učenika koristi usluge Gradske knjižnice Zadar, ali da ne koriste online katalog. Dobiveni rezultati ukazuju na važnost upozna- 
vanja učenika osnovnih i srednjih škola sa svrhom kataloga, s time kako ga i za što mogu koristiti te kako pretraživati online katalog. Iz rezultata anketnog ispitivanja može se zaključiti da je učenicima kako osnovnih tako i srednjih škola tema radionice uglavnom zanimljiva. Određene razlike u mišljenju učenika osnovnih i srednjih škola najviše su se očitovale u odgovorima na pitanja o jasnoći i razumljivosti prezentiranog sadržaja, stjecanju novih znanja i korisnosti novostečenog znanja u daljnjem školovanju. Jasnoća i razumljivost prezentiranog sadržaja ocijenjeni su najvišom ocjenom od svih pitanja zatvorenog tipa, ali u znatno većem postotku od strane učenika srednjih škola. S obzirom na to da su se i na sljedeća dva pitanja o stjecanju novih znanja, kao i o korisnosti novostečenog znanja, učenici srednjih škola pozitivnije izjasnili, nameće se zaključak da je prezentirani sadržaj zahtjevniji za učenike osnovnih škola te da ga je potrebno dodatno prilagoditi. Na pitanje otvorenog tipa o tome koji im je dio radionice najkorisniji, učenici su odgovorili da su to tehnike pretraživanja, napredno pretraživanje, pretraživanje online kataloga te kviz, o čijoj su se korisnosti izjasnili samo učenici osnovne škole, dok ga učenici srednje škole nijednom nisu označili korisnim. Činjenica da su učenici osnovnih i srednjih škola odgovorili kako su im najkorisniji dijelovi radionice tehnike pretraživanja, napredno pretraživanje i pretraživanje online kataloga upućuje na zaključak da su im navedena područja do radionice bila nepoznata.

U pitanjima otvorenog tipa mnogo je učenika pohvalilo radionicu, pri čemu su istaknuli stjecanje novih znanja i vještina s kojima nisu bili upoznati ili ih do sudjelovanja u radionici nisu koristili.

Na temelju analize dobivenih rezultata može se zaključiti da je daljnja provedba programa Informacijsko opismenjavanje tinejdžera Gradske knjižnice Zadar potrebna i da će biti dobro prihvaćena od strane učenika, ali i da su potrebne izmjene programa radi prilagodbe različitim razinama znanja, razumijevanja i iskustva učenika viših razreda osnovne škole te učenika srednje škole.

\section{Zaključak}

Program Informacijsko opismenjavanje tinejdžera Gradske knjižnice Zadar nastao je kao rezultat inicijative pokrenute 2015. godine, kada je izrađen plan programa koji je ušao u Plan i program rada za 2016. godinu, a s ciljem poučavanja korisnika informacijskoj pismenosti. S provođenjem programa započelo se krajem 2016. godine, a do sredine 2018. godine održano je dvadeset radionica, od kojih je deset uključeno u istraživanje.

Razvijanje sposobnosti učinkovitog pronalaženja, korištenja i vrednovanja internetskih izvora i informacija te razvijanje knjižnične pismenosti korištenjem kataloga ciljevi su tog programa, namijenjenog prije svega učenicima viših razreda osnovne škole i učenicima srednjih škola, ali i svim zainteresiranim pojedincima i skupinama. Jedna od uloga narodne knjižnice u zajednici jest obrazovna uloga, 
koja ju definira kao središte učenja koje obuhvaća učenje u formalnom i neformalnom okruženju. Unapređivanje znanja, vještina i kompetencija kroz učenje u svim razdobljima života dovelo je do razvoja koncepta cjeloživotnog učenja koje je poveznica između informacijske pismenosti i narodne knjižnice. Danas narodne knjižnice obrazuju korisnike za korištenje informacija bez obzira na to gdje se oni nalaze, osposobljavajući ih tako za cjeloživotno učenje u promjenjivom informacijsko-komunikacijskom okruženju.

Gradska knjižnica Zadar kroz program Informacijsko opismenjavanje tinejdže$r a$ ostvarila je međuinstitucionalnu suradnju te je programski obuhvatila mlade kao korisničku skupinu pružajući im mogućnost usvajanja novih znanja. Provedenim istraživanjem željelo se doći do pokazatelja koji će pomoći pri vrednovanju i unapređivanju samog programa. Rezultati istraživanja pokazali su da postoji potreba za nastavkom provođenja programa, koji je pozitivno prihvaćen od strane učenika osnovnih i srednjih škola, te da postoji potreba unapređivanja programa u svrhu prilagodbe prethodnim iskustvima polaznika, kao i različitim razinama njihova znanja.

Osmišljavajući i provodeći program Informacijsko opismenjavanje tinejdže$r a$ u radu s mladima i kroz suradnju s odgojno-obrazovnim ustanovama Gradska knjižnica Zadar prepoznala je svoju ulogu u zajednici kao polazišna točka pružanja, pronalaženja i usvajanja novih znanja i informacija.

\section{LITERATURA}

Aparac-Jelušić,T.; M. Kasap. Izazovi knjižnične arhitekture za mlade. // Vjesnik bibliotekara Hrvatske 60, 2-3(2017), 153-174. Dostupno i na: https://www.hkdrustvo.hr/vjesnik-bibliotekara-hrvatske/index.php/vbh/article/view/581/533 [citirano 2018-03-16].

Baier Jakovac, A.; I. Hebrang Grgić. Informacijska (ne)pismenost: istraživanje mladih korisnika knjižnica u Vukovaru. // Knjižničarstvo 19, 1-2(2015), 27-46. [citirano: 2018-06-04]. Dostupno na: http://bib.irb.hr/datoteka/801946.247_Baier-Jakovac_ Hebrang-Grgic_2015_1-2.pdf.

Belevski, M.; S. Segarić. iPad i u našoj školi. // Stručni skup Dječja knjižnica, danas i njezina odgojno obrazovna dimenzija: zbornik radova / uredili Marina Šimić i VilijamLakić. Šibenik: Gradska Knjižnica Juraj Šižgorić, 2017. Str. 61-76.

Cohen, L.; L. Manion; K. Morrison. Metode istraživanja u obrazovanju. Jastrebarsko: Naklada Slap, 2007.

Čunović, K. Poučavanje djece i mladih informacijskoj pismenosti u knjižnicama. // Svezak 12, 12(2010), 10-11. Dostupno i na: https://library.foi.hr/m3/pregled. aspx $? \mathrm{z}=100 \& \mathrm{zad}=\& \mathrm{sql}=\mathrm{SD} 2 \mathrm{CCD}(2 \mathrm{DCD}(\mathrm{DDDC} 2-\mathrm{DDD}-\mathrm{SSDDCD} \& \mathrm{od}=\&-$ $\mathrm{do}=\& \mathrm{~B}=1 \& \mathrm{vrsta}=\&$ grupa $=\& \mathrm{H}=\& \mathrm{X}=\mathrm{S} 02110$ [citirano: 2018-05-30] . 
Edupoint: časopis o primjeni informacijskih tehnologija u obrazovanju 3(2003). [citirano: 2018-06-03]. Dostupno na: http://edupoint.carnet.hr/casopis/17.html.

Etički kodeks istraživanja s djecom / urednici Marina Ajduković, Vladimir Kolesarić. Zagreb: Državni zavod za zaštitu obitelji, materinstva i mladeži: Vijeće za djecu Vlade Republike Hrvatske, 2003. [citirano 2018-03-07]. Dostupno na: http://www.ufzg. unizg.hr/wp-content/uploads/2013/12/Eticki-kodeks-istrazivanja-s-djecom.pdf.

Ferenčić Martinčić, I. Zašto su knjižničari najvažniji ili o informacijskoj pismenosti. // Svezak 12, 12(2010), 11-12. Dostupno i na: https://library.foi.hr/m3/ $\mathrm{kdc} 1 . \mathrm{php}$ ? sqlnivo $=\& \mathrm{sqlid}=1 \& \mathrm{~B}=1 \& \mathrm{sqlx}=\mathrm{S} 02110 \& \mathrm{broj}=201000012 \& \mathrm{volu}-$ men $=12 \& \mathrm{dlib}=\& \mathrm{~L}=\& \mathrm{~F}=\& \mathrm{vrsta}=\&$ grupa $=\& \mathrm{H}=\& \mathrm{U}=\&$ upit $=\& \mathrm{sc}=\& \mathrm{w}=1 . \quad$ [citirano: 2018-05-30].

Gradska knjižnica Zadar. Plan i program rada za 2016. [citirano 2018-02-05]. Dostupno na: http://www.gkzd.hr/sites/default/files/Plan\%20i\%20program\%20gkzd\%20 2016_scan.pdf.

Hadengue, V. What can e-learning do for university libraries? // Library Review 53, 8(2004), 396-400. DOI: https://doi.org/10.1108/00242530410556229

Hrvatsko knjižničarsko društvo. Informacijska pismenost u dječjim knjižnicama. [citirano: 2018-03-15]. Dostupno na: https://www.hkdrustvo.hr/hr/skupovi/skup/316/

Jokić, A.; D. Koljenik; S. FaletarTanacković; B. Badurina. Vještine informacijske i informacijske i informatičke pismenosti studenata informacijskih znanosti u Osijeku: pilot istraživanje. // Vjesnik bibliotekara Hrvatske 59, 3-4(2016), 63-92. Dostupno i na: https://www.hkdrustvo.hr/vjesnik-bibliotekara-hrvatske/index.php/vbh/article/ view/501/47 [citirano: 2018-05-03].

Lau, J. Smjernice za informacijsku pismenost u cjeloživotnom učenju: završna verzija. Recenzirano 30. srpnja 2006. Zagreb: Hrvatsko knjižničarsko društvo, 2011.

Lazić-Lasić, J. ; S. Špiranec; M. Banek Zorica. Izgubljeni u novim obrazovnim okruženjima - pronađeni u informacijskom opismenjivanju. // Medijska istraživanja 18, 1(2012), 125-142. Dostupno i na: https://hrcak.srce.hr/85384[citirano: 2018-01-25].

Maletić, F. Informacija je ponovo „in“. // In Mediasres 3, 5(2014), 716-723. Dostupno i na: https:/hrcak.srce.hr/127202[citirano: 2018-02-15].

Nastavni plan i program za osnovnu školu. 2013.[citirano: 2018-06-04]. Dostupno na: https://mzo.hr/sites/default/files/migrated/nastavni_plan_i_program_za_os_2013.pdf.

Pavičić, J. Strategija marketinga neprofitnih organizacija. Zagreb: Masmedia, 2003.

Pavičić, J.; N. Alfirević; Lj. Aleksić. Marketing i menadžment u kulturi i umjetnosti. Zagreb: Massmedia, 2006.

Poljak, V. Didaktika. 2. prerađeno izd. Zagreb: Školska knjiga, 1991.

Rubinić, D.; I. Stričević. Visokoškolska knjižnica u programima informacijskog opismenjavanja studenata: istraživanje programa Sveučilišne knjižnice Sveučilišta Karl-Franzens Graz // Vjesnik bibliotekara Hrvatske 54, 4(2011), 23-48. Dostupno 
i na: https://www.hkdrustvo.hr/vjesnik-bibliotekara-hrvatske/index.php/vbh/article/ view/338/333 [citirano: 2018-02-22].

Sabolović-Krajina, D. Programi cjeloživotnog učenja u narodnim knjižnicama u jugozapadnoj Njemačkoj. // Svezak 12, 12(2010), 73-74. Dostupno i na: https://library.foi.hr/m3/ pregled.aspx? $\mathrm{z}=100 \& \mathrm{zad}=\& \mathrm{sql}=\mathrm{SD} 2 \mathrm{CCD}(2 \mathrm{DCD}(\mathrm{DDDC} 2-\mathrm{DDD}-\mathrm{SSDD} 73 \& \mathrm{od}=\&-$ $\mathrm{do}=\& \mathrm{~B}=1 \& \mathrm{vrsta}=\&$ grupa $=\& \mathrm{H}=\& \mathrm{X}=\mathrm{S} 02110$ [citirano: 2018-05-30].

Standardi za narodne knjižnice u Republici Hrvatskoj. [citirano: 2018-06-04]. Dostupno na: https://narodne-novine.nn.hr/clanci/sluzbeni/1997_10_105_1616.html.

Standard za školske knjižnice. // Narodne novine 34, 698(2000). [citirano: 2018-06-04]. Dostupno na: https://narodne-novine.nn.hr/clanci/sluzbeni/2000_03_34_698.html.

Stipetić Šušak, J. Informacijsko opismenjavanje u narodnim knjižnicama. // Vjesnik Bibliotekara Hrvatske 59, 3-4(2016), 93-102. Dostupno i na: https://www.hkdrustvo.hr/vjesnik-bibliotekara-hrvatske/index.php/vbh/article/view/502/474 [citirano: 2018-05-10].

Stričević, I.; S. Jelušić. Knjižnične usluge za mlade: modeli i koncepti. // Vjesnik bibliotekara Hrvatske 53, 1(2010), 1-34. Dostupno i na: https://www.hkdrustvo.hr/ vjesnik-bibliotekara-hrvatske/index.php/vbh/article/view/443/438 [citirano 201805-31].

Svezak: časopis Društva knjižničara Bilogore, Podravine i Kalničkog Prigorja / glavna urednica Ljiljana Vugrinec. 12,12(2010). [citirano 2018-05-30]. Dostupno na: https://library.foi.hr/m3/kdc1.php?sqlnivo=\&sqlid=1\&B=1\&sqlx=S02110\&broj= $201000012 \&$ volumen $=12 \& \mathrm{dlib}=\& \mathrm{~L}=\& \mathrm{~F}=\& \mathrm{vrsta}=\&$ grupa $=\& \mathrm{H}=\& \mathrm{U}=\&$ upit $=\& \mathrm{~s}-$ $\mathrm{c}=\& \mathrm{w}=1 \# \mathrm{vrh}$

Špiranec, S. Informacijska pismenost: ključ za cjeloživotno učenje. // Edupoint 3(2003). [citirano: 2018-06-03]. Dostupno na: http://edupoint.carnet.hr/casopis/17/clanci/1.html.

Špiranec, S.; J. Lasić-Lazić. Obrazovna uloga knjižnica: priprema građana za Europu znanja. // Vjesnik bibliotekara Hrvatske 48, 1(2005), 46-55. Dostupno i na: http:// www.hkdrustvo.hr/datoteke/141/vbh/God.48 [citirano: 2014-02-17].

Špiranec, S.; M. Banek Zorica. Informacijska pismenost? Da, mi to možemo... „Yes, we can“. // Svezak 12, 12(2010), 8-10. Dostupno i na: https://library.foi.hr/m3/pregled.aspx? $\mathrm{z}=100 \& z a d=\& \mathrm{sq}=\mathrm{SD} 2 \mathrm{CCD}(2 \mathrm{DCD}$ (DDDC2-DDD-SSDDD8\&od=\&$\mathrm{do}=\& \mathrm{~B}=1 \& \mathrm{vrsta}=\&$ grupa $=\& \mathrm{H}=\& \mathrm{X}=\mathrm{S} 02110$ [citirano: 2018-05-30].

Špiranec, S.; M. Banek Zorica. Informacijska pismenost: teorijski okvir i polazišta. Zagreb: Zavod za informacijske studije, 2008.

Zakon o knjižnicama. // Narodne novine 10, 1616(1997). [citirano: 2018-06-04]. Dostupno na:https://narodnenovine.nn.hr/clanci/sluzbeni/1997_10_105_1616.html.

Zakon o odgoju i obrazovanju u osnovnoj i srednjoj školi (Pročiščeni tekst). // Narodne novine 126, 2705(2012. [citirano: 2018-06-04]. Dostupno na: https://narodne-novine.nn.hr/clanci/sluzbeni/2012_11_126_2705.html 


\section{PRILOG 1.}

Anketni upitnik - Program Informacijskog opismenjavanja tinejdžera u GKZD

Učenik osnovne/srednje škole (razred) (zaokružite)

1. Jeste li do sada koristili usluge knjižnice?

DA NE

2. Koristite li online katalog knjižnice?

DA NE

Molimo Vas da na skali od 1 do 5 ocijenite zadovoljstvo održanom radionicom, pri čemu je

1 - nedovoljno

2 - dovoljno

3 - dobro

4 - vrlo dobro

5 - izvrsno.

1. Kako ocjenjujete zanimljivost teme radionice?

$$
\begin{array}{lllll}
1 & 2 & 3 & 4 & 5
\end{array}
$$

2. Kako ocjenjujete jasnoću i razumljivost sadržaja radionice?

$\begin{array}{lllll}1 & 2 & 3 & 4 & 5\end{array}$

3. Smatrate li da ste na održanoj radionici naučili nešto novo?

$$
\begin{array}{lllll}
1 & 2 & 3 & 4 & 5
\end{array}
$$

4. Koliko će Vam predstavljeni sadržaj koristiti u pisanju školskih zadaća?

\section{$\begin{array}{lllll}1 & 2 & 3 & 4 & 5\end{array}$}

5. Koji Vam je dio radionice bio najkorisniji?

6. Komentari 